\title{
Makna Konsep Akuntabilitas dan Transparansi dari Perspektif Al-Kindi
}

\author{
Armizha Rahmatika ${ }^{1}$, Isnalita ${ }^{2}$ \\ ${ }^{1,2}$ Universitas Airlangga \\ armiie.rahmatika@gmail.com ${ }^{1}$, isnalita@feb.unair.ac.id ${ }^{2}$
}

\begin{abstract}
Cases of bribery involving auditors and auditees become one form of fraud that is difficult to detect. This is because of both parties are equally enjoying the benefits of the outcome of such unethical and immoral behavior. The increasing number of corruption cases, specifically bribes in the government sector from year to year in Indonesia makes the role of public sector auditors such as BPK RI questioned. In addition, some of the perpetrators of corruption are adherents of Islam, which is interesting to criticize because Islam is a religion that upholds the value of honesty and truth. This research used qualitative research method with postmodernism paradigm because the researcher wanted to study the relevance of classical Islamic philosopher, Al-Kindi's thought with the truth value in the accountability and transparency principle. It is done as an effort to integrate the meaning of accountability and transparency principle according to accounting with truth value according to Al-Kindi's thought to get deeper meaning which if useful for auditor in carrying out its function, in order to work in accordance with professional ethic code by upholding ethics and morality value
\end{abstract}

\section{Keywords: bribery, fraud, truth value, accountability, Al-Kindi}

\begin{abstract}
ABSTRAK
Kasus suap yang melibatkan auditor dan auditee menjadi salah satu bentuk fraud yang sulit terdeteksi. Hal tersebut dikarenakan, kedua pihak sama-sama menikmati keuntungan atas hasil dari perilaku yang tidak etis dan tidak bermoral tersebut. Peningkatan jumlah kasus koruspi - suap di sektor pemerintahan dari tahun ke tahun di Indonesia menjadikan peran auditor sektor publik seperti BPK RI dipertanyakan. Selain itu, sebagian pelaku korupsi merupakan penganut agama Islam, dimana hal tersebut menarik untuk dikritisi karena sesungguhnya Islam merupakan agama yang menjunjung tinggi nilai kejujuran dan kebenaran. Penelitian ini menggunakan metode penelitian kualitatif dengan paradigma postmodernisme karena peneliti ingin menelaah relevansi dari pemikiran filsuf islam klasik, Al-Kindi dengan nilai kebenaran dari prinsip akuntabilitas dan transparansi. Hal tersebut dilakukan sebagai salah satu bentuk upaya integrasi makna prinsip akuntabilitas dan transparansi menurut akuntansi dengan nilai kebenaran menurut Al-Kindi sehingga didapatkan pendalaman makna yang sekiranya bermanfaat bagi auditor dalam menjalankan fungsinya dan senantiasa bekerja sesuai dengan kode etik profesi dengan menjunjung tinggi nilai etika dan moralitas.
\end{abstract}

Kata Kunci : suap, fraud, nilai kebenaran, akuntabilitas, Al-Kindi 


\section{PENDAHULUAN}

Auditor bertanggungjawab untuk memberikan opini atas keandalan informasi yang disajikan oleh manajemen dalam laporan keuangan, sehingga dapat diperoleh suatu keyakinan bahwa laporan keuangan tersebut telah bebas dari bias dan salah saji material. Ikatan Akuntan Indonesia telah menerbitkan Standar Akuntansi Keuangan sebagai pedoman bagi auditor agar dapat melaksanakan audit yang sesuai dengan prosedur sehingga menghasilkan suatu output yang dapat dipertanggungjawabkan. Selain itu, kode etik profesi juga diterbitkan guna menjaga objektifitas, independensi, dan integritas auditor, yang mana bila dilakukan dengan baik akan mendatangkan kepercayaan masyarakat.

Pada tingkat negara, kepercayaan masyarakat akan diperoleh ketika pemerintah telah terselenggara secara adil, bersih, akuntabel, dan transparan. Salah satu upaya yang dilakukan pemerintah ialah dengan mendirikan suatu lembaga negara yang independen, yaitu Badan Pemeriksa Keuangan Republik Indonesia (BPK RI) yang bertugas untuk memeriksa kewajaran informasi keuangan yang disajikan dalam laporan keuangan institusi pemerintah untuk selanjutnya memberikan opininya. BPK RI memberikan suatu opini dengan mempertimbangkan beberapa kriteria, yaitu antara lain kesesuaian dengan standar akuntansi pemerintah, kepatuhan terhadap peraturan perundangundangan, pengungkapan yang mencukupi, dan sistem pengendalian intern yang efektif.

Adanya skandal fraud di tahun 2016 yang menyeret anggota BPK dalam kasus jual beli opini yang terungkap pasca dilakukannya Operasi Tangkap Tangan (OTT) oleh KPK menyebabkan kepercayaan publik terhadap BPK menghilang. Hal itu dikarenakan adanya dugaan suap yang melibatkan petinggi BPK dalam memberikan opini Wajar Tanpa Pengecualian (WTP) atas Laporan Keuangan Kemendesa tahun anggaran 2016 dimana sebelumnya BPK memberikan opini Wajar Dengan Pengecualian. Peristiwa suap tersebut dapat terjadi ketika selama pelaksanaan audit terdapat intervensi yang menyebabkan hilangnya sikap independen dari diri auditor. Auditor diharuskan independen saat melakukakan pelaksanaan audit karena adanya tanggungjawab moral yang diembannya, yang mengharuskan auditor mengungkapkan informasi yang benar dan akurat sehingga tidak menghasilkan temuan yang bias dan menyesatkan yang meningkatkan potensi terjadinya fraud. Penelitian terdahulu menemukan bahwa baiknya pelaksanaan audit di sektor publik dapat menjadi salah satu elemen kunci dalam melawan korupsi di tingkat domestik (Gustavson \& Sundström, 2016; Otalor \& Eiya, 2013)

Asosiasi Pemeriksa Keuangan Bersertifikat (ACFE) membagi fraud menjadi tiga kategori, yaitu: kecurangan laporan keuangan (fraudulent statement), penyimpangan aset (asset misappropriation), dan korupsi (Tuanakotta, 2010). Kasus suap yang melibatkan auditor BPK RI dapat dikategorikan sebagai korupsi karena auditor dan auditee saling menikmati keuntungan atas tindak kecurangan yang mereka lakukan bersama. Korupsi merupakan salah satu jenis fraud yang banyak terjadi di negara berkembang karena lemahnya penegakan hukum dan rendahnya kesadaran untuk menerapakan mekanisme governance yang baik.

Albrecht di tahun 1984 mencetuskan adanya fraud scale yang mendasari terjadinya fraud, yaitu: tekanan situasional, kesempatan untuk melakukan kecurangan dan integritas personal dimana integritas personal mengacu pada kode etik personal yang dimiliki oleh tiap individu (Dorminey et al., 2012). Beliau juga menyebutkan bahwa inti dari tindakan fraud adalah pelanggaran terhadap etika, kejujuran dan tanggung jawab. Selain itu, fraud dapat disebabkan oleh tiga faktor, yaitu: rasionalisasi, 
tekanan, dan kesempatan (Cressey, 1950). Rasionalisasi dan tekanan berkaitan erat dengan kondisi psikologis pelaku fraud, dimana keduanya berpengaruh besar pada moralitas dan etika individu (Ramamoorti, 2008). Fraud terjadi ketika terdapat tekanan yang memotivasi seseorang untuk melakukan kecurangan, kemudian didukung dengan pembenaran diri (rasionalisasi) bahwa yang mereka lakukan bukanlah suatu kejahatan, dan adanya kesempatan yang mendorong terjadinya fraud yang disebabkan oleh lemahnya pengendalian internal. Hal itu didukung oleh penelitian yang dilakukan oleh (Coram et al., 2008) dimana organisasi yang mempunyai fungsi internal audit yang baik akan memiliki peluang yang lebih besar dalam mencegah terjadinya fraud.

Risiko terjadinya fraud dalam suatu lembaga dapat dikurangi dengan cara melaksanakan governance yang baik, dimana terdapat sanksi yang harus dipertanggung-jawabkan bila tidak dilakukan sebagaimana seharusnya. Seluruh penyelenggara negara, baik eksekutif, legislatif, maupun yudikatif juga diharuskan memiliki komitmen penuh dalam bekerja sama untuk menegakkan tata kelola yang baik dan mewujudkan pemerintahan yang bersih secara bersama-sama. Peraturan Pemerintah No.60 tahun 2008 menjelaskan tentang Sistem Pengendalian Internal Pemerintah (SPIP), sebagai suatu proses yang integral pada tindakan dan kegiatan yang dilakukan secara terus menerus oleh pimpinan dan seluruh pegawai untuk memberikan keyakinan memadai atas tercapainya tujuan organisasi melalui kegiatan yang efektif dan efisien, keandalan pelaporan keuangan, pengamanan aset negara, dan ketaatan terhadap peraturan perundang-undangan. Oleh karena itu, sebagai salah satu bentuk pertanggungjawabannya, instansi pemerintah daerah diharuskan untuk menerbitkan informasi yang akuntabel dan transparan.

Pemerintah juga perlu melakukan reformasi audit internal dan eksternal dalam pengelolaan keuangan negara (Ayuningtyas, 2012). Reformasi audit ini bertujuan agar pelaksanaan audit di lingkungan instansi pemerintah dapat berjalan lebih baik sehingga dapat mengurangi potensi terjadinya korupsi yang menimbulkan kerugian negara. Salah satu bentuk reformasi audit adalah adanya pelaporan aktivitas pengelolaan dan pertanggungjawaban keuangan di institusi pemerintah secara transparan dan akuntabel.

Implementasi prinsip akuntabilitas dan tranparansi diharapkan dapat menjembatani konflik kepentingan antara masyarakat dengan pemerintah, karena pemerintah akan terdorong untuk menyampaikan informasi secara akurat dan tepat waktu kepada masyarakat. Akuntabilitas merupakan bentuk pertanggungjawaban pemerintah atas penyelenggaraan pemerintahan (contohnya: pengelolaan keuangan negara) yang dilakukannya sehingga dapat menghasilkan suatu informasi yang bermanfaat bagi masyarakat tanpa ada yang perlu disembunyikan (transparan). Kedua prinsip ini sangat berguna dalam mewujudkan suatu mekanisme governance yang baik atas upaya pemerintah mencegah terjadinya korupsi (Ferry \& Eckersley, 2015).

Prinsip akuntabilitas dan transparansi dengan mengedepankan nilai kebenaran merupakan suatu hal mutlak yang perlu diimplementasikan oleh pemerintah untuk mengembalikan kepercayaan masyarakat. Penyimpangan perilaku auditor saat melakukan fraud tentunya dipengaruhi oleh beberapa faktor, baik internal maupun eksternal. Teori atribusi dapat digunakan untuk menjelaskan alasan apa yang mendasari seseorang melakukan fraud - korupsi dalam bentuk suap (Puspasari \& Suwardi, 2012). Robbins (2006) perilaku individu disebabkan oleh faktor internal dan faktor eksternal. Perilaku yang disebabkan oleh faktor internal adalah perilaku yang diyakini berada di bawah kendali atau berasal dari dalam diri individu seperti karakeristik, kepribadian, dan motivasi. Sedangkan, perilaku yang disebabkan oleh faktor eksternal adalah perilaku yang diyakini berasal dari luar diri individu seperti pengaruh sosial dari orang lain. Berdasarkan teori atribusi, dapat disimpulkan bahwa nilai kebenaran dapat 
membentuk perilaku auditor agar sesuai dengan nilai etika dan moralitas yang terdapat dalam kode etik sehingga auditor dalam menjalankan profesinya dengan baik.

Implementasi nilai kebenaran dengan baik dapat membatasi rasionalisasi individu ataupun organisasi agar tetap sesuai dengan nilai moral yang ada sehingga potensi terjadinya fraud dapat diminimalisir. Beberapa dekade terakhir, dimana jumlah kasus korupsi di Indonesia yang semakin meningkat membuktikan bahwa tingkat moralitas individu semakin menurun. Hal tersebut dikarenakan hilangnya kesadaran akan nilai kebenaran yang bersumber dari diri maupun dari Ilahi yang disebabkan oleh banyaknya tekanan yang mendorong manusia untuk tamak dan serakah. Oleh karena itu, penulis ingin menggali kembali definisi prinsip akuntabilitas dan transparansi yang bersumber dari nilai kebenaran menurut filsuf Islam klasik terkemuka, yaitu Al-Kindi. Pencarian makna kembali dilakukan penulis sebagai upaya untuk mewujudkan prinsip akuntabilitas dan transparansi dengan bersumber pada pemikiran filsuf Islam klasik sehingga dapat dan mengingatkan auditor akan makna sesungguhnya dari akuntabilitas dan transparansi. Penelitian ini diharapkan dapat berkontribusi dalam memperluas pemahaman auditor dalam memaknai prinsip akuntabilitas dan transparansi dari perspektif seorang filsuf Islam.

\section{METODE}

Metode penelitian kualitatif digunakan karena penelitian ini bertujuan untuk menjelaskan fenomena yang ada dengan menekankan subjektivitas peneliti dengan berdasarkan data yang akurat dan relevan. Peneliti melakukaan penelahaan atas pemikiran para ahli yang ada dalam artikel, buku, dan sumber lain yang relevan dengan penelitian. Paradigma postmodernisme diigunakan karena peneliti bukan hanya mengkritik suatu makna tetapi juga meletakkan nilai-nilai baru ke dalam makna tersebut. Peneliti memilih tema fraud dalam bentuk suap di B\{K RI karena dalam beberapa tahun terakhir banyak terungkap kasus korupsi yang melibatkan instansi pemerintah tersebut dan masih terdapat sedikit penelitian yang menelitinya. Hal tersebut menjadi suatu topik yang menarik untuk dikritisi karena hampir 100\% individu yang terlibat kasus suap di Indonesia merupakan penganut agama Islam, padahal Islam sendiri sangat menjunjung tinggi nilai kebenaran.

\section{PEMBAHASAN}

\section{A. Fraud dalam BPK RI}

Adanya indikasi fraud dalam laporan keuangan Kemendesa di tahun anggaran 2016 menyebabkan BPK RI memberikan opini Wajar Dengan Pengecualian. Indikasi tersebut dikarenakan adanya pembengkakan biaya operasional yang tidak dapat ditelusuri alirannya. Oleh karena itu, sebagai upaya untuk menutupinya aparat instansi pemerintah tersebut berupaya menyuap atau memberikan uang pelicin untuk memuluskan tujuannya dalam memperoleh opini Wajar Tanpa Pengecualian dari BPK RI. Pelaksanaan audit pemerintah yang sesuai dengan standar akan meningkatkan transparansi kebijakan publik dan mengurangi pengeluaran yang boros (Blume \& Voigt, 2011). Pemberian opini Wajar Tanpa Pengecualian yang diterbitkan oleh BPK atas Laporan Keuangan Kementerian Desa dan PDTT 2016 diharapkan mampu meningkatkan kepercayaan publik atas keberhasilan instansi tersebut dalam melaksanakan amanat rakyat.

Pelaku suap menyiratkan bahwa opini BPK RI merupakan suatu penghargaan atas pencapaian instansi yang dapat memberikan sinyal positif pada publik atas 
keberhasilan suatu instansi dalam mengelola dana pemerintah. Hal tersebut menandakan bahwa opini BPK RI memiliki kekuatan legitimasi yang memaksa instansi pemerintah untuk menerbitkan laporan keuangan yang memenuhi kriteria yang disyaratkan oleh BPK. Suatu instansi pemerintah akan terdorong untuk merasionalkan tindakannya menyuap auditor BPK RI sebagai suatu hal yang benar untuk dilakukan ketika salah satu kriteria tidak terpenuhi. Perilaku yang tidak etis tersebut dikarenakan tingkat kesadaran individu atas pengaruh nilai kebenaran dalam kehidupan manusia masih rendah.

Fraud dapat terjadi dikarenakan rendahnya nilai moralitas yang dimiliki individu, dimana moralitas memiliki kaitan erat dengan etika (Ramamoorti, 2008). Sedangkan, etika memiliki hubungan dengan rasionalisasi yang mendasari terjadinya fraud. Alasan rasionalisasi tersebut didasarkan adanya tekanan atau motivasi yang mendasari individu tersebut untuk mencapai sesuatu yang sebenarnya tidak dapat dicapainya dan bertentangan dengan nilai kebenaran, sehingga mereka akan terpaksa untuk mencari pembenaran untuk perbuatannya. Selain itu, rasionalisasi untuk melakukan fraud dalam sektor pemerintahan akan terjadi ketika tekanan yang muncul diikuti dengan kesempatan yang terbuka lebar (7).

\section{B. Sejarah Singkat Pemikiran Al-Kindi}

Al-Kindi merupakan satu-satunya murid Aristoteles yang berasal dari Timur sehingga dalam proses pengembangan ilmu yang telah dipelajarinya dari filsuf Yunani, Al-Kindi menempatkannya dalam konteks baru, sebelum akhirnya Al-Kindi meletakkan dasar-dasar filosofi baru. Perbedaan cara pandang antara Al-Kindi dengan filsuf Yunani dalam memandang teologi mengakibatkan Al-Kindi lebih memilih menyesuaikan pengetahuan yang diperolehnya dengan doktrin agama. Hal tersebut akan bermanfaat bagi pencarian makna baru mengenai nilai kebenaran karena pemikiran Al-Kindi merupakan hasil pengembangan ilmu yang telah disesuaikan oleh doktrin agama dan pemikiran para ahli filsafat sebelumnya.

\section{Relevansi Pemikiran Al-Kindi tentang Prinsip Akuntabilitas dan Transparansi dengan Akuntansi Modern}

Akuntansi merupakan ilmu pengetahuan yang bersumber pada data historis dan bukti yang relevan dan reliabel yang melalui serangkaian proses sehingga menghasilkan suatu outcome, yaitu berupa informasi yang benar dan akurat. Outcome tersebut merupakan salah satu bentuk pertanggungjawaban auditor kepada masyarakat yang dipengaruhi oleh keahlian dan kondisi psikologinya, dimana auditor diharuskan mempertimbangkan moralitas dan profesionalitasnya dalam menjalankan fungsinya. Bentuk pertanggungjawaban tersebut dinamakan dengan akuntabilitas. Adanya akuntabilitas auditor kepada masyarakat akan mendorong keterbukaan informasi yang dimiliki auditor (transparansi), dimana apabila kedua prinsip tersebut mengedepankan nilai kebenaran dan kejujuran maka informasi yang dihasilkan bebas dari tendensi apapun yang lahir dari kepentingan pribadi. Hal itu menyebabkan individu berusaha untuk mengakui kebenaran yang ada di dalam dirinya dengan jujur sehingga ia tidak akan berupaya untuk merasionalkan suatu perilaku yang sejatinya salah menjadi suatu hal yang benar untuk dilakukan. Hal itu akan mencegah individu tersebut untuk melakukan fraud karena ia akan mengikuti hati nuraninya bukan akalnya yang mendorongnya untuk merasionalisasikan perbuatan tidak etisnya.

Nilai kebenaran manusia juga perlu disertai dengan nilai kebenaran Ilahi agar dapat meningkatkan nilai moralitas individu dalam memaknai kehidupan. Menurut Al- 
Kindi, jalan menuju kebahagiaan duniawi dapat diwujudkan dengan mengurangi keinginan memiliki semua harta benda eksternal seminimal mungkin. Hal tersebut memotivasi individu untuk tidak terpengaruh oleh tekanan yang disebabkan oleh rasa keserakahan yang ada dalam diri manusia. Jalan menuju kebahagiaan duniawi lainnya adalah dengan mengenal Allah dan melakukan tindakan-tindakan yang dapat membawa kita lebih dekat kepada-Nya. Upaya ini dapat dilakukan untuk menjaga individu agar senantiasa memikirkan dan melakukan kebaikan, sehingga dapat mengindari perilaku yang tidak etis dan tidak bermoral.

Prinsip yang mengedepankan nilai kejujuran dalam kehidupan sudah seharusnya bersifat universal. Hal tersebut selaras dengan prinsip akuntabilitas dan transparansi yang mengedepankan nilai kebenaran dalam akuntansi. Secara tidak langsung, akuntansi merupakan ilmu yang mengajarkan kebenaran dan kejujuran. Akuntansi telah mendorong individu untuk berbuat benar dalam segala aktivitas, baik aktivitas ekonomi maupun non-ekonomi, bukan hanya 'berbuat baik'. Hal itu dikarenakan masih adanya pertentangan terkait definisi 'berbuat baik'. Nilai kebaikan akan berbeda-beda bagi setiap orang, tergantung dari perspektif mana orang tersebut melihatnya. Sedangkan, nilai kebenaran akan mengacu pada nilai moral yang terdapat pada masyarakat, dimana moral sendiri bersumber dari nurani manusia.

Hati nurani merupakan anugerah dari Ilahi yang dapat menjadi petunjuk bagi manusia dalam memisahkan kebenaran dengan kejahatan. Sikap yang dilakukan dengan bersumber dari hati nurani niscaya akan mendatangkan manfaat yang baik karena Allah menunjukkan perilaku yang baik dan mulia di mata-Nya melalui hati nurani. Individu yang perilakunya sejalan dengan hati nuraninya akan cenderung bersikap jujur dan menjunjung tinggi nilai kebenaran. Hal tersebut akan mendorong individu untuk berperilaku etis dan bermoral walaupun terkadang muncul beberapa konflik yang disebabkan oleh nafsu duniawi sehingga diperlukan juga keimanan yang kuat. Integrasi sikap jujur dan keimanan yang kuat akan mencegah individu untuk melakukan fraud walaupun ada kesempatan.

"Ketahuilah bahwa dalam jasad terdapat segumpal daging. Jika ia baik, maka baik pula seluruh jasad. Jika ia rusak, maka rusak pula seluruh jasad. Ketahuilah bahwa ia adalah hati." (HR. Bukhari No.52 dan HR. Muslim No 1599)

"Di dalam hati mereka terdapat penyakit, maka Allah menambah penyakit tersebut, dan mereka akan mendapatkan siksa yang pedih akibat apa yang mereka dustakan." (QS: Al-Baqarah: 10)

Sejak tahun 2009 institusi Badan Pemeriksa Keuangan juga telah melakukan serangkaian upaya untuk meningkatkan mutu hasil pemeriksaan BPK dengan tujuan untuk meningkatkan kepercayaan publik terhadap BPK. Hal tersebut dilakukan BPK dengan melaksanakan peer review yang dilakukan oleh institusi sejenis yang berasal dari Belanda dan Polandia. Tujuan peer review ini adalah untuk menilai apakah sistem pengendalian mutu BPK telah didesain dan diimplementasikan secara efektif untuk memberi keyakinan yang memadai bahwa BPK telah mengimplementasikan standar pemeriksaan, kebijakan pemeriksaan, serta prosedur secara memadai.

Upaya BPK dalam mencari nilai kebenaran tersebut perlu diapresiasi sebagai salah satu bentuk dukungan untuk meminimalisir kesempatan yang memungkinkan oknum-oknum instansi pemerintah untuk melakukan kecurangan akuntansi. Al-Kindi mengajarkan bahwa dalam kehidupan, hendaknya kita menjunjung tinggi nilai kejujuran nilai kebenaran, apapun bentuknya dan darimana pun asalnya. Baik pelaku 
suap maupun penerima suap dalam kasus tersebut dapat dinilai tidak menghargai nilainilai kejujuran dan kebenaran. Keduanya memilih menutup mata sehingga mereka berupaya merasionalisasi perilakunya sebagai suatu hal yang benar untuk dilakukan.Sebagaimana yang telah dijelaskan sebelumnya, Al-Kindi menegaskan bahwa dalam mencari dan mengakui nilai kebenaran, manusia dapat mendapatkannya darimana pun.

"Kita seharusnya tidak menjadi malu menghargai kebenaran dan mendapatkan di mana pun datangnya, bahkan jika itu berasal dari ras yang jauh dan negara yang berbeda dari kami. Tidak ada yang harus didambakan untuk para pencari kebenaran dari kebenaran itu sendiri, dan tidak ada kekeliruan dari kebenaran, atau meremehkan salah satu dari orang yang berbicara atau menyampaikan itu."

"Kita tidak boleh malu untuk mengakui kebenaran dari sumber apa pun datang kepada kita, bahkan jika itu dibawa kepada kami oleh mantan generasi dan bangsa asing. Baginya yang mencari kebenaran tidak ada nilai yang lebih tinggi daripada kebenaran itu sendiri."

\section{KESIMPULAN}

Berdasarkan penjelasan tersebut, dapat disimpulkan bahwa akuntansi bukan sebatas angka. Akuntansi merupakan gabungan dari ilmu sosial dan ilmu jiwa. Kaitannya dengan ilmu sosial, adalah peranan akuntansi dalam mendorong individu untuk menghasilkan informasi yang benar dan akurat sehingga menghasilkan opini yang kredibel dan nantinya dapat mendatangkan manfaat bagi para penggunanya. Sedangkan, kaitannya dengan ilmu jiwa adalah akuntansi mendorong pelakunya agar bertindak sesuai dengan nilai kebenaran manusia dan nilai kebenaran Ilahi. Adanya nilai kebenaran manusia akan mendorong auditor untuk mempertanggungjawabkan perannya dalam masyarakat, yaitu sebagai orang yang dipercayai masyarakat untuk menghasilkan informasi yang benar, tepat, kredibel dan akuntabel.

Sementara itu, dengan adanya nilai kebenaran Ilahi, auditor akan terdorong untuk mengungkapkan kebenaran dan kejujuran walaupun terkadang keduanya tidak sesuai dengan keinginan. Selain itu, adanya nilai kebenaran Ilahi mendorong auditor untuk berperilaku baik karena dalam dirinya tidak ada keserakahan yang mengedepankan nafsu duniawi semata. Hal ini akan mencegah individu untuk bersikap tamak dan membenarkan setiap perilaku tidak etisnya, salah satunya korupsi. Terakhir, akuntansi merupakan ilmu yang mengharuskan pelakunya untuk menyelaraskan akal dan nurani, demi terciptanya kebaikan bagi masyarakat semesta.

\section{DAFTAR PUSTAKA}

Ayuningtyas, H. (2012). Pengaruh Pengalaman Kerja, Independensi, Objektifitas, Integritas, dan Kompetensi terhadap Kualitas Hasil Audit. Diponegoro Journal of Accounting, 1(02), 1-10. 
Blume, L., \& Voigt, S. (2011). Does organizational design of supreme audit institutions matter? A cross-country assessment. European Journal of Political Economy, 27(2), 215-229.

Coram, P., Ferguson, C., \& Moroney, R. (2008). Internal audit, alternative internal audit structures and the level of misappropriation of assets fraud. Accounting \& Finance, 48(4), 543-559.

Cressey, D. R. (1950). The criminal violation of financial trust. American Sociological Review, 15(6), 738-743.

Dorminey, J., Fleming, A. S., Kranacher, M.-J., \& Riley Jr, R. A. (2012). The evolution of fraud theory. Issues in Accounting Education, 27(2), 555-579.

El-Ehwany, Ahmed Fouad. Al-Kindi. A History of Muslim Philosophy Volume 1, Book 3. Pakistan

Ferry, L., \& Eckersley, P. (2015). Accountability and transparency: a nuanced response to Etzioni. Public administration review, 75(1), 11-12.

Gustavson, M., \& Sundström, A. (2016). Organizing the Audit Society: Does Good Auditing Generate Less Public Sector Corruption? Administration \& Society, 0095399716674306.

Otalor, J. I., \& Eiya, O. (2013). Combating corruption in Nigeria: The role of the public sector auditor. Research Journal of Finance and Accounting, 4(4), 122-131.

Puspasari, N., \& Suwardi, E. (2012). Pengaruh Moralitas Individu Dan Pengendalian Internal Terhadap Kecenderungan Kecurangan Akuntansi: Studi Eksperimen Pada Konteks Pemerintahan Daerah. Jurnal. FEB UGM, Yogyakarta.

Ramamoorti, S. (2008). The psychology and sociology of fraud: Integrating the behavioral sciences component into fraud and forensic accounting curricula. Issues in Accounting Education, 23(4), 521-533.

Tuanakotta, T. M. (2010). Audit Forensik dan Audit Investigatif: Jakarta: Salemba Empat.

\section{Sumber Internet}

Kumar, Asnawi. Al-Kindi Filosof Muslim Pertama, diakses melalui tribunnews.com tanggal 24 Juni 2016.

Editorial, Tim. Al-Kindi, diakses melalui muslimheritage.com tanggal 24 Juni 2016. 